\title{
Cellular and Molecular Mechanisms for Reduced Interleukin 4 and Interferon- $\gamma$ Production by Neonatal T Cells
}

\author{
David B. Lewis," Charles C. Yu, ${ }^{\star}$ Jeff Meyer, ${ }^{\star}$ B. Keith English, ${ }^{*}$ Stuart J. Kahn, ${ }^{*}$ and Christopher B. Wilson ${ }^{\star s}$ \\ ${ }^{*}$ Divisions of Immunology/Rheumatology and Infectious Diseases, Departments of Pediatrics and Immunology, \\ University of Washington and Children's Hospital and Medical Center, Seattle, Washington 98105; \\ and ${ }^{\ddagger}$ Immunex Corporation, Seattle, Washington 98101
}

\begin{abstract}
The mechanisms by which $T$ lymphocytes acquire the capacity to produce interleukin 4 (IL-4) and other lymphokines during intrathymic and extrathymic development are poorly understood. To gain insight into this process, we determined the capacity of human neonatal and adult $T$ lineage cell populations to produce IL-4 after polyclonal activation. IL-2 and interferon- $\gamma$ $($ IFN- $\gamma$ ) production were studied in parallel, since their production by neonatal $\mathbf{T}$ cells is known to be similar or diminished, respectively, compared to adult $\mathrm{T}$ cells. Production of $\mathrm{IL}-4$ by neonatal $\mathrm{CD4}^{+} \mathrm{T}$ cells and IFN- $\gamma$ by neonatal $\mathrm{CD4}^{+}$and $\mathrm{CD8}^{+}$ $T$ cells was markedly lower compared with analogous adult cell populations, whereas IL-2 production was similar. Transcription of IL-4, as determined by nuclear run-on assays, and IL-4 mRNA-containing cells, as determined by in situ hybridization, were undetectable in neonatal $\mathrm{T}$ cells, whereas both were detectable in adult $T$ cells. IFN- $\boldsymbol{\gamma}$ transcription and IFN- $\boldsymbol{\gamma}$ mRNAcontaining cells were reduced in neonatal $T$ cells compared with adult $\mathbf{T}$ cells. Reduced lymphokine production by neonatal $\mathbf{T}$ cells correlated with their lack of a CD45R ${ }^{-}$(putative memory $T$ cell) population; cells with this surface phenotype comprised $30-40 \%$ of the adult $\mathrm{CD4}^{+} \mathrm{T}$ cells and were highly enriched for IL- 4 and IFN- $\gamma$, but not IL-2 production. IL-4, IFN- $\gamma$, and IL-2 mRNA expression by neonatal $\mathrm{CD4}^{+} \mathrm{CD8}^{-}$thymocytes was similar to that found in circulating neonatal $\mathrm{CD4}^{+} \mathrm{T}$ cells. Taken together, these findings suggest that the extrathymic generation of memory $T$ cells during postnatal life may result in an increased capacity for IL- 4 and IFN- $\gamma$ gene expression. In addition, IFN- $\gamma$ and IL-2 mRNA were significantly more abundant than IL-4 mRNA in activated neonatal $\mathrm{CD4}^{+} \mathrm{CD8}^{-}$thymocytes and $\mathrm{CD4}^{+} \mathrm{T}$ cells, as well as adult $\mathrm{CD4}^{+} \mathrm{CD45R}^{-} \mathrm{T}$ cells. Therefore, the capacity of $T$ lineage cells to express the IL-4 gene may be more restricted compared to other lymphokine genes beginning in intrathymic development. This restricted capacity appears to persist during postnatal extrathymic maturation of T cells. (J. Clin. Invest. 1991. 87:194-202.). Key words: $C D 45 \bullet$ interferon- $\gamma \bullet$ interleukin $4 \cdot$ memory T cells - neonatal T cells
\end{abstract}

\section{Introduction}

Secretion of lymphokines such as the interleukins (IL) IL-2 and IL- 4 and interferon- $\gamma($ IFN- $\gamma)$ by activated $T$ cells is an essen-

Address reprint requests to Dr. Lewis, Division of Immunology/Rheumatology, Children's Hospital and Medical Center, P.O. Box C-5371, Seattle, WA 98105.

Received for publication 15 December 1989 and in revised form 8 July 1990.

J. Clin. Invest.

(c) The American Society for Clinical Investigation, Inc. 0021-9738/91/01/0194/09 \$2.00

Volume 87, January 1991, 194-202 tial component of antigen-specific immunity (1-3). How T cells acquire, during their intrathymic and extrathymic maturation, the capacity to produce particular lymphokines remains largely unknown. Recently we have shown that virtually all IL- 4 and most IFN- $\gamma$ produced by polyclonally activated adult $\mathrm{CD}^{+} \mathrm{T}$ cells is mediated by a CD45 $\mathrm{R}^{-}$subset, whereas $\mathrm{CD}_{45 \mathrm{R}^{+}}$and $\mathrm{CD} 45 \mathrm{R}^{-} \mathrm{CD}^{+} \mathrm{T}$ cells produce comparable amounts of IL-2 (4); the CD45 ${ }^{-}$subset, which is enriched in functional memory cells and is $\mathrm{UCHL1}^{+}$, appears to be derived from $C D 45 R^{+}$(virgin) $T$ cells which have been activated in vivo, presumably by suitably presented cognate antigen (5-9). We reasoned that if previous in vivo activation is a major determinant of the capacity for T cells to produce IL-4 and IFN- $\gamma$, then neonatal $\mathrm{T}$ cells, which presumably have had a minimal exposure to exogenous antigens, should exhibit a profile of lymphokine production similar to that of adult virgin $T$ cells. In agreement with this prediction, reduced IFN $-\gamma$ production by neonatal $\mathrm{T}$ cells compared to adult $\mathrm{T}$ cells has been noted by us and other workers (10-14). We now report that such a selective reduction in both IL-4 as well as IFN- $\gamma$ gene expression by activated neonatal $\mathrm{T}$ cells does occur. This pattern of lymphokine production correlates with a uniformly CD45R ${ }^{+}$surface phenotype on neonatal $\mathrm{T}$ cells, and is largely transcriptionally regulated. A similar selective reduction in IL-4 and IFN- $\gamma$ compared with IL-2 gene expression was observed in $\mathrm{CD}^{+}$, $\mathrm{CD}^{-}$thymocytes, suggesting that the results with neonatal $\mathrm{T}$ cells may reflect in part their antigenically naive status.

\section{Methods}

Monoclonal antibodies (MAb). The following murine anti-human MAb were used for either cell purification or flow cytometric analysis: 9.6, anti-CD2, IgG2a (15); OKT4, anti-CD4, IgG2b (16); 66.1, antiCD4, IgM (17); OKT8, anti-CD8, IgG2a (18); FC-1, anti-CD16, IgM (19); 3AC5, anti-CD45R (200-, 220-kD isoforms), IgG2a (20, 21); and UCHL1, anti-CD45 (180-kD isoform), $\operatorname{IgG} 2 \mathrm{a}(21,22)$. The 9.6 and 66.1 MAb were provided by Dr. Paul Martin, Fred Hutchinson Cancer Research Center, Seattle, WA; FC-1 and 3AC5 MAb by Dr. Edward Clark, University of Washington, Seattle, WA; and UCHL1 MAb by Dr. Peter C. L. Beverley, Imperial Cancer Research Fund-Human Tumour Immunology Unit, London, UK. The OKT4 and OKT8 hybridomas were purchased from the American Type Culture Collection, Rockville, MD. RPC-5 (IgG2a) and MOPC-195 (IgG2b) murine MAb, which served as isotype-specific negative controls for flow cytometric analysis were purchased from Litton Bionetics, Kensington, MD as affinity-purified preparations. All other MAb were used in the form of sterile ascites except for UCHL1 which was used as a sterile hybridoma culture supernatant.

Cell preparations. Peripheral blood mononuclear cells (PBMC) were isolated from the peripheral blood of adult volunteers or umbilical cord blood of healthy term neonates using Ficoll-Hypaque density gradient centrifugation (23), and $T$ cells were prepared by treatment of PBMC with T cell Lymphokwik, (One Lambda, Los Angeles, CA) as previously described (4). T cell preparations were routinely $\geq 97 \%$ 
CD2-positive as assessed by flow cytometry after indirect immunofluorescent staining with MAb 9.6. $\mathrm{CD}^{+}$and $\mathrm{CD}^{+} \mathrm{T}$ cell subsets were purified by negative selection using MAb and complement: $T$ cells were incubated with saturating concentrations of either OKT8 or 66.1 MAb, respectively, for 30 min at $4^{\circ} \mathrm{C}$ in RPMI-1640 medium (Mediatech, Washington, DC) containing 2\% FCS (Hyclone Laboratories, Logan, UT). The anti-CD16 MAb, FC-1 was included in these incubations to deplete residual NK cells. After washing at $4^{\circ} \mathrm{C}$, the cells were resuspended in RPMI medium with $20 \%$ (vol/vol) HLA-typing grade rabbit complement (Pel-Freez Biologicals, Brown Deer, WI) and incubated at $37^{\circ} \mathrm{C}$ for $1 \mathrm{~h}$ with gentle agitation. Remaining viable cells were collected by Ficoll-Hypaque density gradient centrifugation and washed twice in RPMI medium with $2 \%$ fetal calf serum (FCS) before use. Adult $\mathrm{CD}^{+} \mathrm{T}$ cells were further fractionated into $\mathrm{CD} 45 \mathrm{R}^{+}$and CD45R $\mathrm{R}^{-}$populations by incubation with MAb UCHL1 or $3 A C 5$, respectively, followed by negative selection with indirect panning (24) using plastic petri dishes (Baxter Scientific Products, McGaw Park, IL) previously coated with affinity-purified goat anti-mouse IgG (Tago Inc., Burlingame, CA). Human thymus samples were obtained from neonates undergoing cardiac surgery for congenital heart disease who were free of other significant congenital anomalies. After removal of fibrous capsular tissue and grossly visible blood vessels, samples were finely minced and pressed through sieves, and the viable thymocytes were collected by Ficoll-Hypaque centrifugation. $\mathrm{CD}^{+} \mathrm{CD}^{-}$singlepositive thymocytes were prepared by incubating unfractionated thymocytes with MAb OKT8 for 30 min at $4^{\circ} \mathrm{C}$ in RPMI medium with $2 \%$ FCS. The cells binding MAb were lysed using rabbit complement and the remaining viable cells subsequently isolated as described above for the purification of the $\mathrm{CD}^{+}$and $\mathrm{CD}^{+}$peripheral $\mathrm{T}$ cells. The purity of all T cell and thymocyte subsets was $>95 \%$ as determined by immunofluorescent flow cytometry after indirect staining with appropriate MAb.

$T$ cell and thymocyte activation. Cells $\left(5 \times 10^{6} / \mathrm{ml}\right)$ were incubated with either $0.5 \mu \mathrm{M}$ ionomycin (Calbiochem-Behring Corp., San Diego, CA), $25 \mu \mathrm{g} / \mathrm{ml}$ concanavalin A (Con A; Pharmacia Fine Chemicals, Piscataway, NJ), or OKT3 (anti-CD3) MAb (18) (1:25 [vol/vol] of sterile azide-free ascites) in combination with $50 \mathrm{ng} / \mathrm{ml}$ phorbol myristate acetate (PMA; Sigma Chemical Co., St. Louis, MO); these concentrations were found to be optimal for lymphokine induction in preliminary experiments. RPMI 1640 medium containing 5\% (vol/vol) human $\mathrm{AB}$ serum was used in all cases except for experiments assaying IL-4 and IFN- $\gamma$ protein in cell culture supernatants, for which AIM-V, a commercial serum-free medium (Gibco Laboratories, Grand Island, NY), was employed. Both media were supplemented with $2 \mathrm{mM} \mathrm{L-glu-}$ tamine, $50 \mathrm{U} / \mathrm{ml}$ penicillin $\mathrm{G}$, and $50 \mu \mathrm{g} / \mathrm{ml}$ streptomycin.

$I L-4$ and IFN- $\gamma$ protein assay. T cell culture supernatants were collected after $24 \mathrm{~h}$ of ionomycin and PMA treatment and concentrated using a Centricon-10 apparatus (Amicon Corp., Danvers, MA)

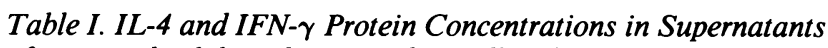
of Activated Adult and Neonatal T Cell Cultures

\begin{tabular}{cll}
\hline Cell type & IL-4 & IFN- $\gamma$ \\
\hline
\end{tabular}

$p M$

$\begin{array}{ccc}\text { Adult } & & \\ \text { A } & 14.6 & 1762 \\ \text { B } & 34.6 & 4164 \\ \text { C } & 26.8 & 4766 \\ \text { D } & 46.0 & \text { ND } \\ \text { Neonate } & & \\ \text { A } & <3.5 & 30.0 \\ \text { B } & <3.5 & 29.5 \\ \text { C } & <3.5 & 26.5 \\ \text { D } & <3.5 & \text { ND }\end{array}$

as previously described (4). The IL-4 and IFN- $\gamma$ content of concentrated supernatants was determined by radioimmunoassay (RIA) as described $(4,25)$. The final IL- 4 and IFN- $\gamma$ concentrations reported are calculated for cell culture supernatants before concentration, assuming $100 \%$ recovery. The recovery of samples spiked with recombinant human IL- 4 or IFN- $\gamma$ and concentrated was $\sim 70-80 \%$. The results for IL-4 and IFN- $\gamma$ protein concentrations for three of these adult T cell supernatants have been reported previously (4). For both IL-4 and IFN- $\gamma$ RIA determinations, neonatal and adult $T$ cell samples were analyzed in parallel.

In vitro transcription with isolated nuclei. Transcription assays were performed as previously described (26), using nuclei isolated from $T$ cells after 1.5 or $3 \mathrm{~h}$ of incubation with ionomycin and PMA.

RNA blot analysis. Total cellular RNA was isolated by the guanidinium thiocyanate/CsCl method (27), electrophoresed in $2.2 \mathrm{M}$ formaldehyde, $1 \%$ agarose gels, blotted, hybridized, and washed as previously described $(4,14) .{ }^{32} \mathrm{P}$-labeled RNA probes were synthesized from human IL-4 (28), IFN- $\gamma$ (29), and IL-2 (30) cDNAs subcloned into transcription vectors, using a commercially available kit (Promega Biotech, Madison, WI). The human elongation factor 1- $\alpha(\mathrm{EF})^{1} \mathrm{cDNA}$ probe (provided by $R$. Perlmutter, University of Washington) was ${ }^{32} \mathrm{P}$ labeled by the random hexamer primer method (31). The cDNAs were all full length except for IFN- $\gamma$ for which a $0.4-k b$ internal fragment was used (14).

In situ hybridization. In situ hybridization was performed exactly according to the method of Pardoll et al. (32), using ${ }^{35}$ S-labeled singlestranded anti-sense or sense RNA probes prepared from the IL-4, IFN$\gamma$, and IL-2 cDNAs as previously described (4). After counter staining with Diff-Quik reagent according to the manufacturer's instructions (Dade Diagnostics, Aguada, Puerto Rico) slides were permanently mounted and coded. For each slide, the number of grains over 300 individual cells was determined by counting 75 cells in each of four randomly selected fields free of obvious artifacts. Cells were considered positive for a mRNA species if their grain counts after hybridization with the antisense probe exceeded that of $99 \%$ of cells hybridized with the control sense probe.

Indirect immunofluorescent staining and flow cytometric analysis. Unless otherwise indicated, PBS (pH 7.4) containing 1\% BSA and 0.1\% sodium azide was used to dilute all reagents and for cell washes. Cells were washed once and then incubated with saturating concentrations of diluted sterile MAb for $30 \mathrm{~min}$ at $4^{\circ} \mathrm{C}$. After two washes, the cells were incubated with affinity purified fluorescein isothiocyanate (FITC)-labeled goat anti-mouse IgG or IgM $F\left(a^{\prime}\right)_{2}$ fragments (Tago Inc.) diluted 1:40 (vol/vol). The cells were subsequently washed three times and fixed in $2 \%$ paraformaldehyde/PBS for $5 \mathrm{~min}$ at room temperature, and then transfered to PBS. At least $3 \times 10^{3}$ cells per sample were analyzed using a flow cytometer (Epics $\mathrm{C}$, Coulter Electronics, Inc., Hialeah, FL) equipped with a 2-W argon laser.

\section{Results}

Decreased production of IL-4 and IFN- $\gamma$ by neonatal $T$ cells. After treatment with ionomycin and PMA, which induces maximal IL-4 and IFN- $\gamma$ production by adult T cells (4), IL-4 concentrations exceeded $10 \mathrm{pM}$ in cell culture supernatants from three different adult donors but were below the $3.5 \mathrm{pM}$ limit of detectability in all neonatal samples (Table I). Unlike IL-4, IFN- $\gamma$ was detectable in all neonatal T cell culture supernatants, but in concentrations $(25-30 \mathrm{pM})$ that were uniformly $<10 \%$ of those measured in adult $\mathrm{T}$ cell supernatants (Table I), as reported previously $(4,13,14)$. Nevertheless, IFN- $\gamma$ production by neonatal $T$ cells was significantly greater than IL-4 pro-

1. Abbreviations used in this paper: EF, elongation factor 1- $\alpha$; LCA, leukocyte common antigen; PKC, protein kinase $\mathrm{C}$. 
duction on a molar basis, as previously reported for adult $\mathrm{T}$ cells (4).

Decreased IL-4 and IFN- $\gamma$ production reflects diminished gene transcription and $m R N A$ accumulation. The production of IFN- $\gamma$ and IL- 2 by T cells appears to be primarily regulated by the rate at which these lymphokine genes are transcribed (33-37). To determine whether decreased IL-4 and IFN- $\gamma$ protein production by neonatal $\mathrm{T}$ cells was also regulated in this manner, the transcription rates of the IL- 4 and IFN- $\gamma$ genes were compared in cell nuclei purified from activated adult and neonatal T cells (Fig. 1). The IL-2 gene, whose product is expressed in similar amounts by adult and neonatal T cells (1214 ), and the EF gene, whose transcript comprises $\sim 0.5 \%$ of mRNA in most types of mammalian cells (4), were transcribed at similar rates by nuclei from adult and neonatal $\mathrm{T}$ cells and served as positive controls in these and subsequent experiments. IL- 4 gene transcription by activated adult $\mathrm{T}$ cells was detectable as shown by the greater signal with the slot-blotted IL-4 cDNA plasmid than the negative control plasmid (Fig. 1 $B)$. However, the IL-4 gene appeared to be transcribed in adult $T$ cells at a markedly lower rate than the IFN- $\gamma$, IL-2, or EF genes, and, unlike these other genes, required high concentrations of labelled nuclear RNA to detect its transcription (Fig. 1, $A$ vs. $B$ ). In contrast, IL-4 gene transcription by neonatal T cells was not clearly detectable (as shown by a signal essentially equal to that of the negative control) even when high concentrations of labelled transcripts were used for hybridization (Fig. $1 B$ ), and the rate of IFN- $\gamma$ gene transcription, although measurable, was much lower than in adult T cells (Fig. $1 A$ ). Thus, the

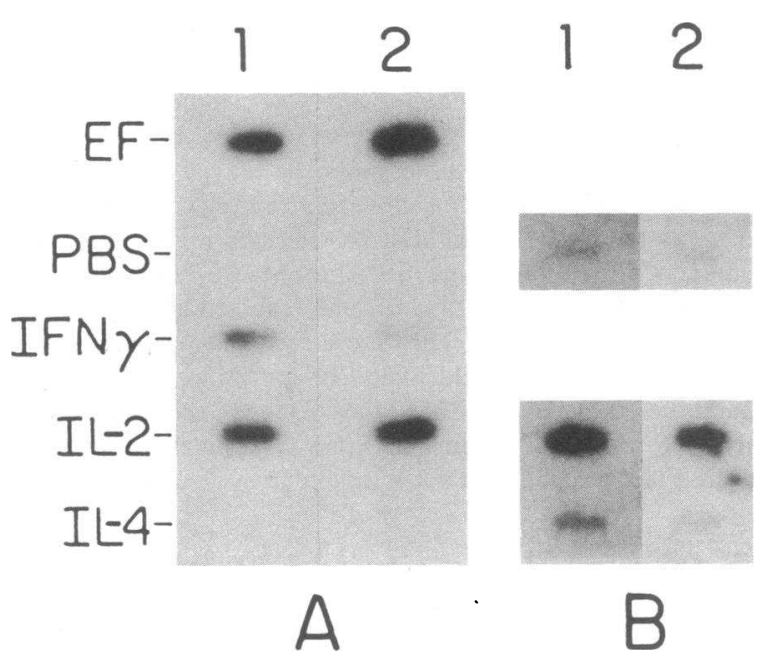

Figure 1. Transcription rates of the IL-4, IFN- $\gamma$, IL-2, and EF genes in nuclei from activated adult and neonatal T cells; PBS refers to the negative control, the plasmid, pBluescribe. $(A)$ Nuclei from adult (lane 1 ) or neonatal T cells (lane 2) incubated with ionomycin and PMA for $3 \mathrm{~h}$. Both filters were hybridized with $1.0 \times 10^{6} \mathrm{dpm} / \mathrm{ml}$ of ${ }^{32}$ P-labeled transcripts. (B) Nuclei from adult (lane $l$ ) or neonatal T cells (lane 2) incubated with ionomycin and PMA for $1.5 \mathrm{~h}$. Both filters were hybridized with $2.5 \times 10^{6} \mathrm{dpm} / \mathrm{ml}$ of ${ }^{32} \mathrm{P}$-labeled transcripts. Integrated densitometry of the bands done with a densitometer (Visage 60, BioImage, Ann Arbor, MI) after subtraction of the values for the PBS negative control, gave the following results (arbitrary units): experiment $A$-adult (lane 1 ) EF 7.0, IFN- $\gamma 2.3$, IL-2 5.8, IL-4 -; neonatal (lane 2) EF 10.1, IFN- $\gamma$ 0.5, IL-2 6.5, IL-4 -; experiment $B$-adult (lane 1) IL-4 1.03, IL-2 11.93; neonatal (lane 2) IL-4 0.16, IL-2 6.35. transcription rates of the IL-4 and IFN- $\gamma$ genes in adult and neonatal T cells corresponded well with the amounts of IL-4 and IFN- $\gamma$ protein these cells secreted, suggesting that production of these lymphokines was largely regulated at a transcriptional level in both cell types.

The decreased transcription of the IL- 4 and IFN- $\gamma$ genes by neonatal $\mathrm{T}$ cells was associated with diminished steady-state levels of these lymphokine mRNAs (Fig. $2 \mathrm{~A}$ ). Adult T cells contained markedly more IL-4 mRNA than did neonatal cells, in which such transcripts were in some cases completely undetectable (Fig. 2, $A$ and $B$ ). IFN- $\gamma$ mRNA was routinely measurable after a shorter period of exposure of autoradiographs than was necessary for the detection of IL- 4 mRNA, consistent with the relative concentrations of these lymphokines in culture supernatants. Although T cells from different individuals varied in their levels of IL-2 mRNA, in general, the amounts of these transcripts in adult and neonatal $\mathrm{T}$ cells were comparable as previously reported $(4,13,14)$. Similar results for IL-4, IFN- $\gamma$, and IL-2 mRNA accumulation were also observed using T cells from an additional six adult and six neonatal subjects (data not shown), and when other stimuli were used (either Con $\mathrm{A}$ and PMA or anti-CD3 $\mathrm{mAb}$ and PMA-see Fig. 2, $B$ and $C$ ), indicating that these differences were not unique to particular individuals or the conditions used for cell activation. Because these other stimuli were generally less effective than ionomycin and PMA, in subsequent experiments cells were stimulated with ionomycin and PMA to maximize detection of the IL-4 and IFN- $\gamma$ gene products.

The markedly reduced levels of IL- 4 and IFN- $\gamma$ mRNA in neonatal $\mathrm{T}$ cells were not attributable to kinetic differences between adult and neonatal cells in the accumulation of these transcripts (Fig. $2 C$ ). In both cell types, lymphokine mRNA was undetectable before in vitro activation (lanes $l$ and 8 ) and peak levels of IL-4, IFN- $\gamma$, and IL- 2 mRNA were achieved by $\sim 6 \mathrm{~h}$ of incubation with ionomycin and PMA or Con A and PMA. In neonatal T cells, IL-4 mRNA, if measurable, was only observed at $6 \mathrm{~h}$ of incubation and not at later times (data not shown). After hybridization with a full-length IL-2 cDNA probe as shown in Fig. $2 C$, transcripts were observed at $24 \mathrm{~h}$ of incubation in neonatal and adult $T$ cells, which had a lower apparent molecular weight than those which accumulated by 6 $\mathrm{h}$ of incubation (lanes 4, 7, and 11). However, these late-appearing transcripts were undetectable after hybridization with an IL-2 cDNA probe which lacked the last $100 \mathrm{bp}$ of the $3^{\prime}$ untranslated region but included the entire coding sequence (30), whereas the earlier-appearing transcripts were still present (data not shown). Thus, these late-appearing transcripts presumably did not encode IL-2, but cross-hybridized with a portion of the ${ }^{\prime}$ untranslated region of the IL-2 gene. EF mRNA was present in activated neonatal and adult $\mathrm{T}$ cells in similar amounts, indicating that the differences observed in lymphokine mRNA accumulation were not attributable to differences in the amount of RNA analyzed in each lane.

Expression of IL-4,IFN- $\gamma$, and IL-2 mRNA by $T$ cell subsets. Because IL-4 mRNA was measurable by RNA blotting in at least some activated neonatal $T$ cell samples under conditions in which IL-4 gene transcription or secreted IL-4 protein was undetectable, we used this more sensitive technique to compare lymphokine gene expression by adult and neonatal $\mathrm{CD}^{+}$and $\mathrm{CD}^{+} \mathrm{T}$ cells after ionomycin and PMA activation (Fig. 3). In agreement with previous observations (4), among adult $\mathrm{T}$ cells, the $\mathrm{CD} 4^{+}$subset was enriched for IL-2 and IL-4 


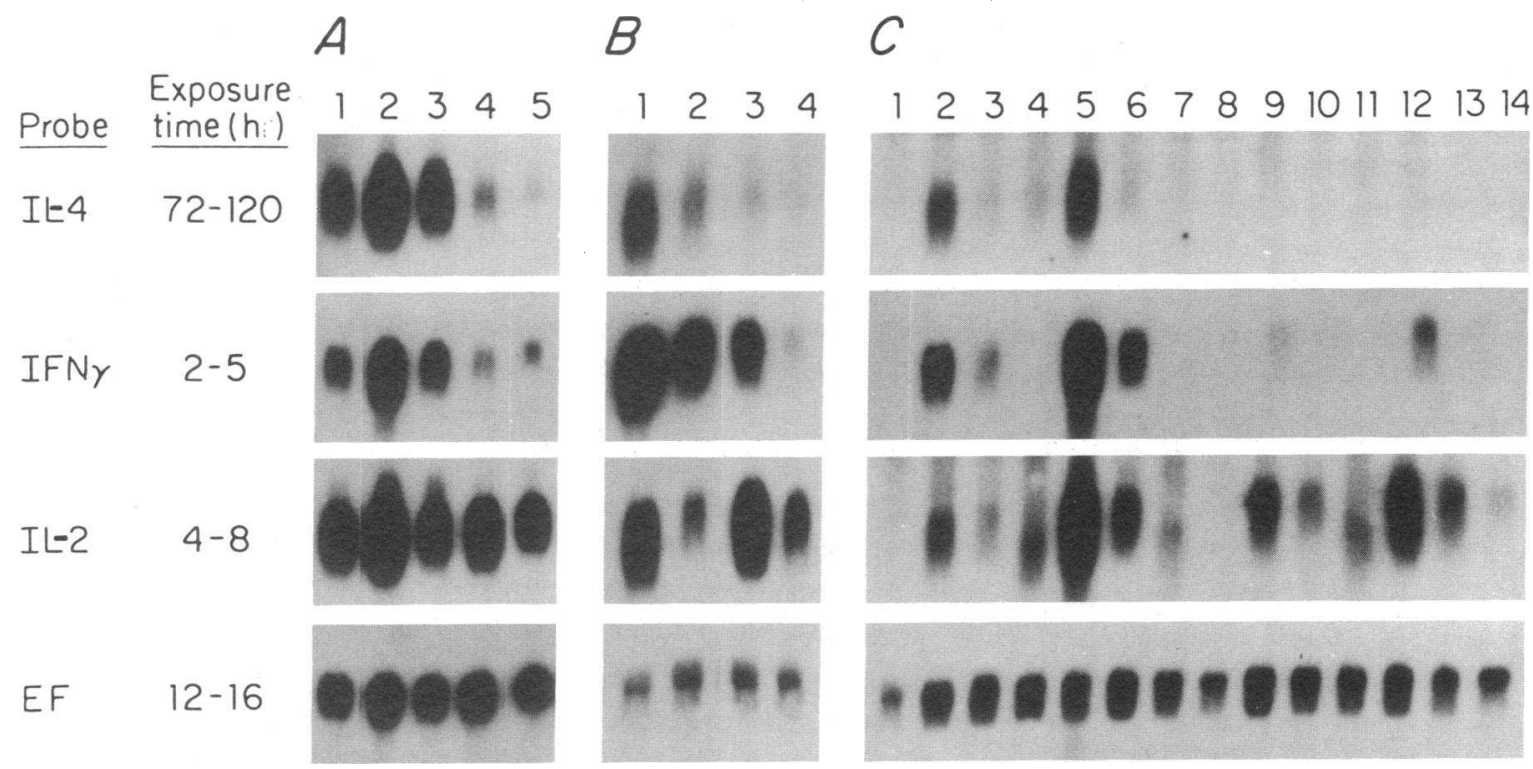

Figure 2. Total RNA samples hybridized with IL-4, IFN- $\gamma$, IL-2, and EF probes. All blots are representative of at least three different experiments. $(A) \mathrm{T}$ cells lymphokine mRNA accumulation after ionomycin and PMA incubation for $6 \mathrm{~h}$. Lanes $1-3$, adult T cells from three different individuals. Lanes 4 and 5 , neonatal $\mathrm{T}$ cells from two different individuals. $(B)$ Lymphokine mRNA accumulation in adult vs. neonatal $\mathrm{T}$ cells under different conditions of activation. Lanes 1 and 2 , adult $\mathrm{T}$ cells incubated for $6 \mathrm{~h}$ with ionomycin and PMA or OKT3 and PMA, respectively. Lanes 3 and 4, neonatal T cells incubated for $6 \mathrm{~h}$ with ionomycin and PMA or OKT3 and PMA, respectively. $(C)$ Kinetics of lymphokine mRNA accumulation in adult vs. neonatal T cells. Lanes $1-4$, adult T cells incubated for $0,6,12$, and $24 \mathrm{~h}$, respectively, with Con A and PMA. Lanes 5-7, adult T cells incubated for 6, 12, and $24 \mathrm{~h}$, respectively, with ionomycin and PMA. Lanes 8-11, neonatal T cells incubated for $0,6,12$, and $24 \mathrm{~h}$, respectively, with Con A and PMA. Lanes 12-14, neonatal T cells incubated for 6, 12, and $24 \mathrm{~h}$, respectively, with ionomycin and PMA. All lanes were loaded with $5 \mu \mathrm{g}$ of total RNA, except for lanes 3 and 4 of $B$ in which $10 \mu \mathrm{g}$ of total RNA was loaded.

mRNA, whereas the $\mathrm{CD} 8^{+}$subset was enriched for IFN- $\gamma$ transcripts (lanes 1 and 2). The marked reduction in IL-4 mRNA, but similar amounts of IL-2 mRNA observed in unfraction-

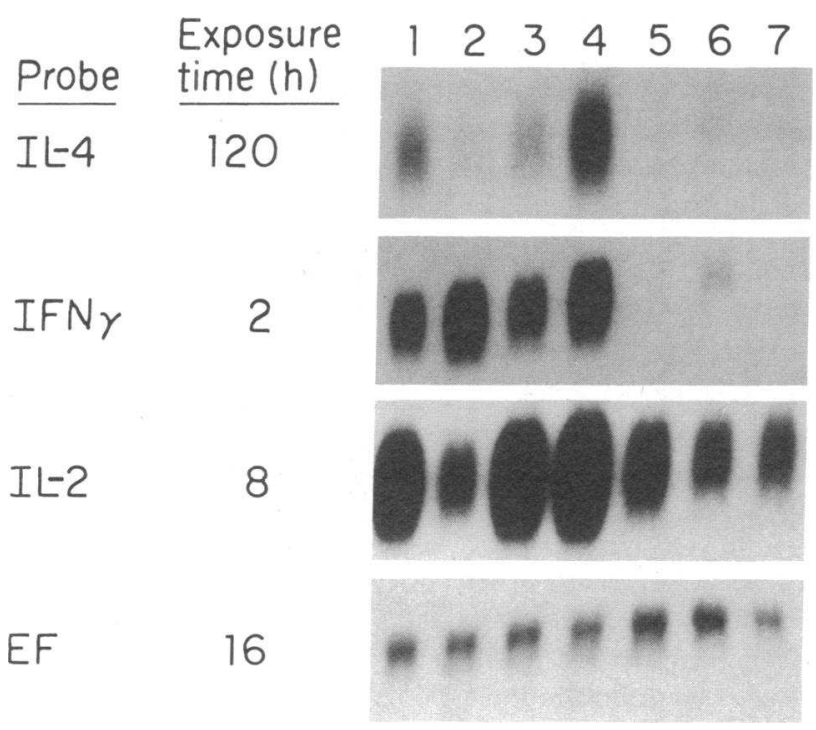

Figure 3. Total RNA samples from subsets of adult and neonatal T cells and neonatal thymocytes after incubation with ionomycin and PMA for 6 h, hybridized with IL-4, IFN- $\gamma$, IL-2, and EF probes. This blot is representative of two separate experiments. Lanes 1 and 2 , adult $\mathrm{CD}^{+}$and $\mathrm{CD} 8^{+} \mathrm{T}$ cells, respectively. Lanes 3 and 4 , adult $\mathrm{CD}^{+} \mathrm{CD}^{+} 5 \mathrm{R}^{+}$and $\mathrm{CD} 4^{+} \mathrm{CD} 45 \mathrm{R}^{-} \mathrm{T}$ cells, respectively. Lanes 5 and 6 , neonatal $\mathrm{CD}^{+}$and $\mathrm{CD}^{+} \mathrm{T}$ cells, respectively. Lane 7 , neonatal $\mathrm{CD}^{+} \mathrm{CD}^{-}$thymocytes. All lanes were loaded with $5 \mu \mathrm{g}$ of total RNA. ated neonatal $\mathrm{T}$ cells compared to adult cells, was also found in purified neonatal $\mathrm{CD}^{+} \mathrm{T}$ cells (lane 1 vs. lane 5 ). Like adult $\mathrm{T}$ cells, the $\mathrm{CD}^{+}$subset of neonatal T cells was enriched in IFN$\gamma$ mRNA and the $\mathrm{CD}^{+}$subset was enriched for IL-2 mRNA, but differences between $\mathrm{CD} 4^{+}$and $\mathrm{CD} 8^{+}$neonatal $\mathrm{T}$ cells and between $\mathrm{CD}^{+}$adult and neonatal T cells in IL- 4 mRNA levels could not be evaluated because of their very low to undetectable amounts of IL- 4 transcripts.

The relatively low levels of IL- 4 and IFN- $\gamma$ mRNA in activated neonatal $T$ cells could be explained by either a reduced number of cells expressing these mRNAs or a reduced level of IL- 4 or IFN- $\gamma$ transcripts per cell or both. To distinguish between these possibilities, we performed in situ hybridization. Results representative of one of three such experiments are shown in Fig. 4 and Table II. Among activated adult cells, IFN- $\gamma$ and IL- 2 mRNA was expressed by $\sim 40 \%$ of T cells, and in a greater percentage of $\mathrm{CD}^{+}$and $\mathrm{CD}^{+} \mathrm{T}$ cells respectively, whereas IL-4 mRNA expression appeared restricted to a small fraction ( $\leq 5 \%$ ) of $\mathrm{CD}^{+} \mathrm{T}$ cells, as previously described (4). In striking contrast, IL-4 mRNA was undetectable in all neonatal $T$ cell fractions (Fig. 4 and Table I), even after autoradiographic exposure of slides for up to $5 \mathrm{wk}$ (data not shown). All neonatal $T$ cell fractions also had markedly fewer cells with detectable IFN- $\gamma$ mRNA. In those neonatal $\mathrm{CD}^{+}$or $\mathrm{CD}^{+} \mathrm{T}$ cells which were positive for IFN- $\gamma$ transcripts, the average amount of IFN- $\gamma$ mRNA per cell, as assessed by grain counts, was lower than in the adult cell population (Fig. 4, data not shown). Like adult cells, neonatal $\mathrm{CD}^{+}$and $\mathrm{CD}^{+} \mathrm{T}$ cells were enriched for IL-2 and IFN- $\gamma$ transcripts respectively, compared to unfractionated $\mathrm{T}$ cells, in agreement with the results obtained by RNA blotting. 

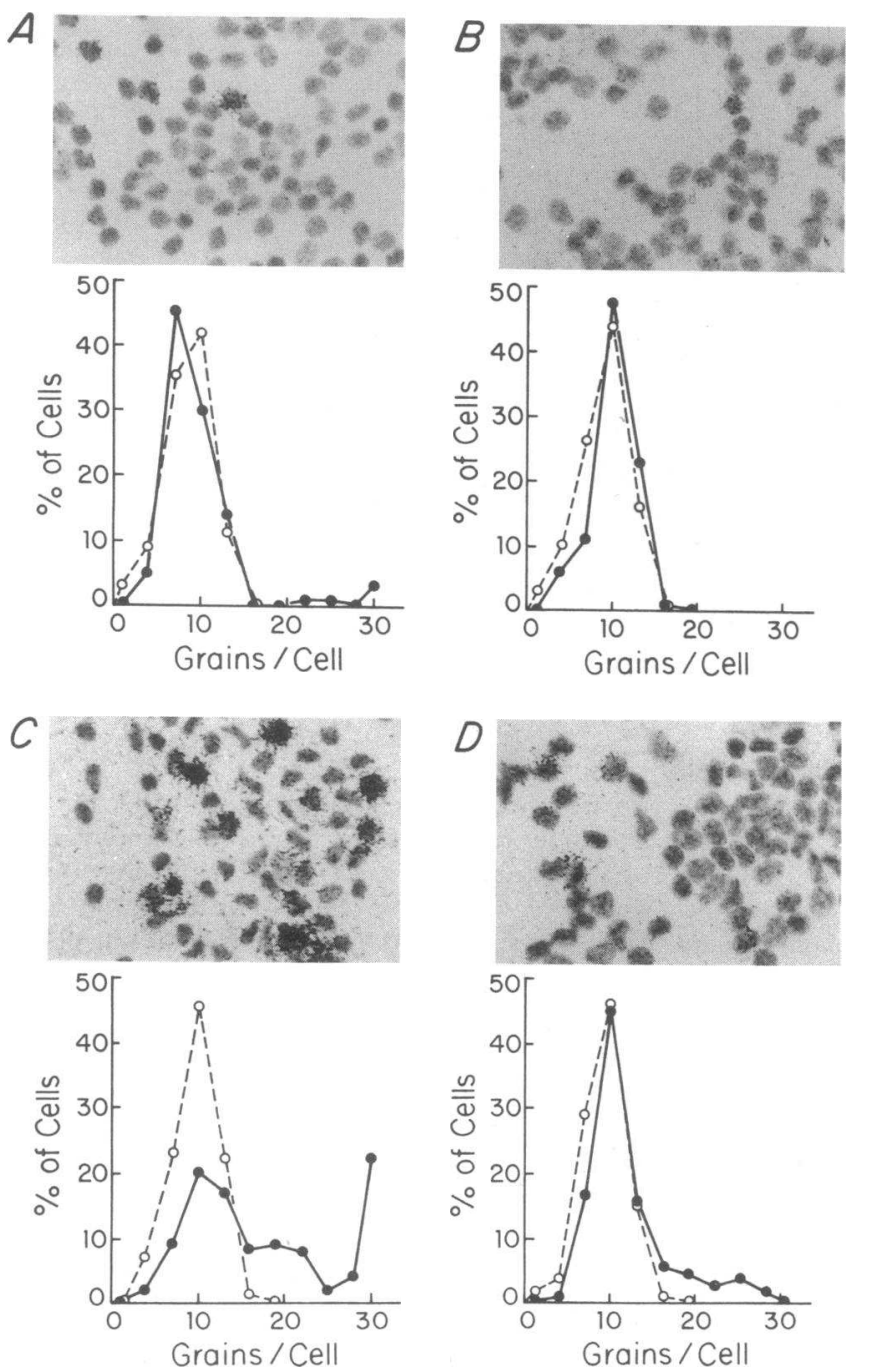

Figure 4. Adult or neonatal $\mathrm{T}$ cells after incubation with ionomycin and PMA for $6 \mathrm{~h}$, hybridized in situ for IL- 4 and IFN- $\gamma$ mRNA. Photomicrographs $(\times 24)$ of adult $(A$ and $C)$ or neonatal $(B$ and $D) \mathrm{T}$ cells hybridized with an anti-sense probe for IL-4 ( $A$ and $B)$ or IFN- $\gamma$ $(C$ and $D)$. Directly below each photomicrograph is the corresponding histogram of the number of grains per cell after hybridization with an antisense probe (•) for the slide depicted, or with a control sense probe (o) by use of a duplicate slide processed in parallel. All slides were exposed for $7 \mathrm{~d}$ before development.

Expression of IL-4, IFN- $\gamma$, and IL- 2 mRNA by CD45R ${ }^{+}$or $C D 45 R^{-} C D 4^{+} T$ cells. Because IL-4 production by adult $\mathrm{T}$ cells appeared to be almost exclusively limited to a small fraction of $\mathrm{CD}^{+} \mathrm{T}$ cells which was undetectable in the peripheral blood of neonates, we sought to further define this population. Previous studies have shown that $\mathrm{CD}^{+} \mathrm{T}$ cells that augment $\mathrm{B}$ cell immunoglobulin production are enriched in proliferative responses to recall antigens and express the $180-\mathrm{kD}$ isoform of the leukocyte common antigen (LCA) (recognized by MAb UCHL1), whereas the mutually exclusive subset of $\mathrm{CD}^{+}$cells that expresses the 200 - and $220-\mathrm{kD}$ isoforms of the LCA, CD45R (recognized by MAb 3AC5), are ineffective in providing such help and are not enriched in functional memory cells $(6-9,38,39)$. These two LCA isoforms do not appear to identify distinct lineages but rather $T$ cells which have $\left(C D 45 R^{-}\right.$,
Table II. IL-4, IFN- $\gamma$, and IL-2 mRNA Expression in Adult or Neonatal T Cells and T Cell Subsets after Activation with Ionomycin and PMA for $6 \mathrm{~h}$

\begin{tabular}{lccc}
\hline & \multicolumn{3}{c}{ Cells positive for mRNA } \\
\cline { 2 - 4 } Cell type & IL-4 & IFN- $\gamma$ & IL-2 \\
\hline Unfractionated T cells & & $\%$ & \\
$\quad$ Adult & 3 & & \\
$\quad$ Neonate & $<1$ & 3 & 42 \\
CD4 ${ }^{+}$T cells & & & 35 \\
$\quad$ Adult & 4 & 34 & 51 \\
$\quad$ Neonate & $<1$ & 2 & 45 \\
CD8 ${ }^{+}$T cells & & & \\
Adult & 1 & 58 & 20 \\
Neonate & $<1$ & 4 & 16 \\
& &
\end{tabular}

The results presented are representative of three (unfractionated $T$ cells) or two (CD4 ${ }^{+}$and $\mathrm{CD} 8^{+} \mathrm{T}$ cells) separate experiments. Slides hybridized with the IL-4 probe were exposed for $14 \mathrm{~d}$, whereas those hybridized with the IFN- $\gamma$ and IL-2 probes were exposed for $7 \mathrm{~d}$.

$\left.\mathrm{UCHLl}^{+}\right)$or have not $\left(\mathrm{CD}^{2} 5 \mathrm{R}^{+}, \mathrm{UCHL1}^{-}\right)$been previously primed by their exposure to cognate antigen in vivo $(7-9,40$, 41 ), although this interpretation has been disputed by others (42). The CD45 $\mathrm{R}^{-}$subpopulation of adult $\mathrm{CD}^{+} \mathrm{T}$ cells is enriched in the production of IL-4 as well as IFN- $\gamma$ (4). Recently others have found that nearly all neonatal $\mathrm{T}$ cells are $\mathrm{CD} 4 \mathrm{R}^{+}, \mathrm{UCHL1}^{-}(5,43,44)$. By immunofluorescent flow cytometry we confirmed that both $\mathrm{CD}^{+}$and $\mathrm{CD}^{+}$neonatal $\mathrm{T}$ cells were almost all CD45R (3AC5)-positive and UCHL1-negative or dull; in contrast, similar populations of adult $\mathrm{T}$ cells demonstrated the previously described $(7-9,40,41)$ bimodal pattern of surface staining: $\sim 40 \%$ of cells expressed UCHL1 and $\sim 60 \%$ of cells expressed CD45R in a mutually exclusive manner (data not shown).

Thus, to directly compare their lymphokine mRNA expression with that by neonatal $\mathrm{CD}^{+}{ }^{+} \mathrm{T}$ cells, adult $\mathrm{CD}^{+} \mathrm{T}$ cells were fractionated into $\mathrm{CD}_{45 \mathrm{R}^{+}}\left(\mathrm{UCHLl}^{-}\right)$and $\mathrm{CD}_{45 \mathrm{R}^{-}}$ $\left(\mathrm{UCHLl}^{+}\right)$subsets. Cell purification was accomplished by negative selection using MAb 3AC5 and UCHL1, since the activation characteristics of $T$ cells can be altered by treatment with MAb directed against LCA (19). IL-4 mRNA expression in adult $\mathrm{CD}^{+} \mathrm{T}$ cells was virtually limited to the $\mathrm{CD} 45 \mathrm{R}^{-}$fraction and IFN- $\gamma$ mRNA expression was also highly enriched in this fraction (Fig. 3, lanes 1 and 4). Activated neonatal CD4 ${ }^{+}$ and adult $\mathrm{CD}^{+}{ }^{+} \mathrm{CD} 45 \mathrm{R}^{+} \mathrm{T}$ cells contained similarly low to undetectable amounts of IL- 4 mRNA and markedly lower levels of IFN- $\gamma$ mRNA (lanes 3 and 5) compared to the CD45R ${ }^{-}$ fraction of adult $\mathrm{CD}^{+} \mathrm{T}$ cells (lane 4 ). Similar amounts of IL-2 mRNA were found in the CD45R ${ }^{+}$and CD45R $\mathrm{R}^{-}$fractions of adult $\mathrm{CD}^{+}{ }^{+} \mathrm{T}$ cells, as well as in neonatal $\mathrm{CD} 4^{+} \mathrm{T}$ cells.

Production of IL-4, IFN- $\gamma$, and IL-2 $\mathrm{mRNA}$ by $C D 4^{+} \mathrm{CD} 8^{-}$ thymocytes. These results suggested that diminished production of IL- 4 and IFN- $\gamma$ by neonatal $\mathrm{CD}^{+}$and adult $\mathrm{CD}^{+}$ CD45R $\mathrm{R}^{+} \mathrm{T}$ cells might reflect their antigenically naive or virgin status. If this were so, then a similar pattern of lymphokine expression might be expected for $\mathrm{CD}^{+} \mathrm{CD}^{-}$thymocytes, a relatively mature population which includes $\mathrm{CD}^{+} \mathrm{T}$ lineage 
cells destined to emigrate into the circulation (45). This was largely true, in that $\mathrm{CD}^{+} \mathrm{CD}^{-}$neonatal thymocytes completely lacked detectable IL-4 mRNA and had low amounts of IFN- $\gamma$ mRNA similar to those of neonatal $\mathrm{CD}^{+} \mathrm{T}$ cells. In addition, this thymocyte subset had slightly reduced levels of IL-2 and EF mRNA compared with adult or neonatal CD4 ${ }^{+} \mathrm{T}$ cells (Fig. 3, lanes 5 and 7). The staining of this filter with methylene blue after hybridizations were completed indicated that equivalent amounts of ribosomal RNA were present in all lanes (data not shown). Similar results were obtained using $\mathrm{CD}^{+} \mathrm{CD}^{-}$thymocytes from older children (data not shown).

\section{Discussion}

We found that IL-4 production by unfractionated and CD4 ${ }^{+}$ neonatal $\mathrm{T}$ cells was markedly and consistently reduced compared to adult cells after polyclonal activation. We also found that IFN- $\gamma$ production both by $\mathrm{CD}^{+}$and $\mathrm{CD} 8^{+}$neonatal $\mathrm{T}$ ceils was diminished compared to adult cells, as previously reported for unfractionated $T$ cells $(4,13,14)$. The decreased IL- 4 and IFN- $\gamma$ production is selective in that production by neonatal and adult T cells of IL-2 (this report and references 4 , and 12-14) and of tumor necrosis factor- $\alpha$ and $-\beta$ and the IL-2 receptor $\mathrm{p} 55$ chain $(13,46)$ are comparable. IL- 4 production by neonatal $\mathrm{T}$ cells was usually undetectable, apparently because of the complete absence of a relatively rare subpopulation present in circulating adult $\mathrm{T}$ cells that produced this lymphokine. IFN- $\gamma$-producing neonatal $\mathrm{T}$ cells, although detectable, were decreased in number and produced lower amounts of IFN- $\gamma$ per cell compared to adult T cells. Decreased IL-4 and IFN- $\gamma$ production by neonatal $\mathrm{CD}^{+}$and $\mathrm{CD}^{+} \mathrm{T}$ cells correlated with the complete absence of CD45R ${ }^{-} \mathrm{T}$ cells which are highly enriched for IL-4 and IFN- $\gamma$-producing cells (4). The results obtained for lymphokine production by neonatal $\mathrm{CD} 4^{+} \mathrm{CD} 8^{-}$ thymocytes paralleled those for circulating neonatal $\mathrm{CD}^{+} \mathrm{T}$ cells, and suggested that absent IL-4 production and reduced IFN- $\gamma$ production by neonatal $\mathrm{T}$ cells was a functional phenotype established during intrathymic development. The undetectable amount of IL- 4 and reduced amount of IFN- $\gamma$ protein secreted by neonatal $\mathrm{T}$ cells was paralleled by proportional decreases in the transcription rates of the IL- 4 and IFN- $\gamma$ genes as well as accumulation of their cognate mRNA, indicating that this decreased lymphokine production was primarily transcriptionally mediated.

In previous reports, reduced IFN- $\gamma$ production by mitogen activated neonatal leukocytes or $\mathrm{T}$ cells has been variously attributed to suppression mediated by radiosensitive $\mathrm{CD}^{+}$or $\mathrm{CD}^{+} \mathrm{T}$ cell populations $(47,48)$. However, our studies of IFN$\gamma$ mRNA expression in bulk cultures or at the individual cell level did not corroborate these findings in that purified $\mathrm{CD4}^{+}$ or $\mathrm{CD}^{+}$neonatal $\mathrm{T}$ cells did not accumulate substantially more IFN- $\gamma$ or IL- 4 mRNA than did unfractionated neonatal $T$ cells. Although our results also do not exclude the possibility of suppression of neonatal T cell IFN- $\gamma$ and IL- 4 production by a population found in both the $\mathrm{CD}^{+}$and $\mathrm{CD} 8^{+}$subsets, a more direct explanation is that reduced expression of these lymphokines is a feature intrinsic to naive $T$ cells or, at least, $T$ cells at this stage of development.

There is increasing evidence that memory $\mathrm{T}$ cells, defined as those which have previously been activated or "primed" by antigen, are capable of increased levels of lymphokine production, compared to antigenically naive, virgin $T$ cells. $T$ cell fractionation studies making use of the mutually exclusive expression of CD45R and the 180-kD LCA isoform (recognized by MAb UCHL1 in humans), or markers coexpressed with the $180-\mathrm{kD}$ isoform, such as 4B4 (CDw29), LFA-3, and in the mouse, PgP-1 (CD44), have demonstrated that postimmunization proliferative recall responses to soluble antigens, viruses, and alloantigens are mediated by $\mathrm{CD}^{4} 5 \mathrm{R}^{-} \mathrm{T}$ cell populations $(6-9,38,49,50)$. In humans, this memory $T$ cell-enriched CD45 $\mathrm{R}^{-}$subset accounts for virtually all IL- 4 and most IFN- $\gamma$ produced by polyclonally activated adult $\mathrm{CD}^{+} \mathrm{T}$ cells $(4)$, and IL-4 production by adult $\mathrm{CD}^{+} \mathrm{T}$ cells also appears to be restricted to a CD45R $\mathrm{R}^{-}$subpopulation (D. B. Lewis and C. B. Wilson, unpublished observations). Similarly in mice, $\mathrm{CD}^{+}$or $\mathrm{CD}^{+} \mathrm{T}$ cells with high surface levels of $\mathrm{PgP}-1$ are markedly enriched in IFN- $\gamma$ production compared to PgP- 1 dull or unfractionated $\mathrm{T}$ cells $(51)$. This enhanced lymphokine produc-

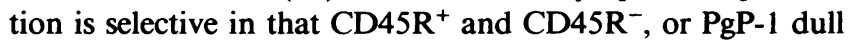
and $\mathrm{PgP}-1$ bright $\mathrm{T}$ cell populations produce similar amounts of IL-2 $(4,9,50)$. The observation originally made by Tedder et al. (5) and confirmed by others $(43,44)$, that human neonatal $T$ cells are uniformly CD45R $\mathrm{R}^{+}$whereas circulating adult $\mathrm{T}$ cells are $\sim 60 \% \mathrm{CD} 45 \mathrm{R}^{+}$, led them to propose that CD45R $R^{+} \mathrm{T}$ cells are converted to a CD45 $R^{-}$surface phenotype by a post-thymic maturational process involving, at least in part, $T$ cell activation by cognate antigen (6). The present study confirmed that both $\mathrm{CD}^{+}$and $\mathrm{CD}^{+}$neonatal $\mathrm{T}$ cells had a CD45R ${ }^{+}$ $\mathrm{UCHL1}^{-}$phenotype, consistent with their presumed antigenically naive status. This model is also supported by the fact that human neonatal or adult $\mathrm{CD}_{45 \mathrm{R}^{+}} \mathrm{T}$ cells polyclonally activated in vitro acquire a $\mathrm{CD} 45 \mathrm{R}^{-} \mathrm{UCHL}^{+}$surface phenotype $(7,9,40,41)$ and by recent adoptive transfer studies in the rat directly demonstrating that $C D 45 R^{+} T$ cells are the precursors of the antigen specific CD45 $\mathrm{R}^{-}$memory population (52). Taken together, these findings strongly suggest that the similar amount of IL-2, but markedly diminished amounts of IL- 4 and IFN- $\gamma$ produced by neonatal $T$ cells compared to adult $T$ cells is due to the absence of an antigenically primed, or at least previously activated, memory $\mathrm{T}$ cell subpopulation.

Studies of postnatal $\mathrm{T}$ cell maturation also support a model in which increased lymphokine production is induced by antigenic priming. Mitogen-induced IFN- $\gamma$ production by peripheral leukocytes increases with postnatal age, as does the number of circulating CD45R- $T$ cells $(43,53)$, although a direct connection between these events has not been established. Additional evidence comes from longitudinal studies of IFN- $\gamma$ production in humans after neonatal or adult infection with herpes simplex virus (HSV): peripheral blood mononuclear cells from 2-mo-old infants who were infected as neonates, produced as much IFN- $\gamma$ in response to HSV antigen as cells from adults 2 mo after primary HSV infection, suggesting that once neonates developed T cells responsive to recall HSV antigens, the capacity of these cells to secrete IFN- $\gamma$ was similar to that of $\mathrm{T}$ cells responding to the same antigen from infected adults (Burchett, S. K., K. Mohan, J. Westall, R. Ashley, L. Corey, and C. B. Wilson, manuscript submitted for publication). In cells from these infants, IFN- $\gamma$ production after HSV antigen stimulation was equivalent to that observed after polyclonal activation with Con $\mathrm{A}$, consistent with the notion that virtually all $\mathrm{T}$ cell-mediated IFN- $\gamma$ production was by memory cells. In contrast, adult $\mathrm{T}$ cells produced much larger amounts of IFN- $\gamma$ after Con A treatment than after HSV antigen stimulation, presumably because Con $A$ activated significant num- 
bers of memory $T$ cells directed against antigens other than HSV that would be expected to be present in adults but not in neonates. Whether antigen-specific IFN- $\gamma$ production after neonatal or adult infection is predominantly mediated by $\mathrm{CD}_{45 \mathrm{R}^{-}} \mathrm{T}$ cells, and antigen-specific IL-4 production parallels that for IFN- $\gamma$ remains to be determined.

Although the above studies suggest that humans can develop functional memory $T$ cells as early as 2 mo of age, they do not exclude the possibility that this ability is impaired at birth but rapidly matures during postnatal development. Several observations are consistent with this idea. First, in cells from infants infected with HSV as neonates, peak IFN- $\gamma$ production by memory $T$ cells does not occur until $\sim 6$ wk after infection, whereas adult cells achieve peak responses after only 2 weeks (Burchett, S. K., K. Mohan, J. Westall, R. Ashley, L. Corey, and C. B. Wilson, manuscript submitted for publication). Whether this delay reflects differences in events occurring proximal to $\mathrm{T}$ cell activation, such as in antigen-processing and presentation, or reflects a decrease in antigen-specific $T$ cells or their ability to be clonally expanded, remains to be determined. In previous studies, the antigen-presenting ability of neonatal and adult mononuclear cells in vitro has been comparable (54). Secondly, immunization of full-term infants with T-dependent antigens is often ineffective during the first 2 wk of life, but results in significant antibody responses when performed at 2 mo of age (55). Although decreased neonatal B cell function or interference by maternal antibodies has been proposed to account for these results, a maturational defect in cognate help by $\mathrm{T}$ cells is plausible. Finally, neonatal $\mathrm{T}$ cells obtained at birth express uniformly high levels of the CD38 antigen (recognized by MAb OKT10), which is also found on virtually all thymocytes but only very small numbers of circulating adult $C D 45 R^{+} T$ cells $(56,57$, and D. B. Lewis and C. B. Wilson, unpublished observations), suggesting that they are, in part, an immature, transitional population. The kinetics of disappearance for circulating CD $38^{+} \mathrm{T}$ cells postnatally, and whether this population acquires a $\mathrm{CD} 38^{-}$phenotype, or is replaced by a new population of $\mathrm{CD} 38^{-} \mathrm{T}$ cells, remains to be determined. Because surface expression of the CD38 antigen is also increased after $T$ cell activation (58), this may limit its usefulness as a marker with which to follow the extrathymic maturation of neonatal $\mathrm{T}$ cells.

A direct comparison of the ability of neonatal and adult CD45R ${ }^{+} \mathrm{T}$ cells to develop into functional memory $\mathrm{T}$ cells would, therefore, be of interest. One approach is to compare lymphokine production by neonatal and adult CD45R ${ }^{+}$populations after in vitro priming. Priming of adult murine $T$ cells using antigens, mitogens, or anti-CD3 MAb increases IL-4 and IFN- $\gamma$, but not IL-2 production; this appears to mimic the in vivo process by which antigen activation selectively enhances lymphokine production (59-62). These studies are in progress.

Stimulated neonatal $\mathrm{CD}^{+}{ }^{+} \mathrm{CD} 8{ }^{-}$thymocytes contained undetectable amounts of IL- 4 mRNA, and low levels of IFN- $\gamma$ mRNA compared to adult CD45R $\mathrm{RD}^{-} \mathrm{C}$ cells, a pattern of lymphokine $\mathrm{mRNA}$ expression similar to that of circulating neonatal $\mathrm{CD}^{+}$or adult $\mathrm{CD} 45 \mathrm{R}^{+} \mathrm{CD} 4^{+} \mathrm{T}$ cells. In addition, the greater capacity for IL- 2 production by $\mathrm{CD}^{+}$and for IFN- $\gamma$ production by $\mathrm{CD}^{+}$circulating neonatal $\mathrm{T}$ cells, is also observed for the $\mathrm{CD}^{+} \mathrm{CD}^{-}$and $\mathrm{CD}^{-} \mathrm{CD}^{+}$subsets of human thymocytes, respectively (D. B. Lewis, unpublished observations). Although these observations suggest that the capacity for lymphokine gene expression by circulating virgin $T$ cell populations is largely determined during intrathymic differentiation, $\mathrm{CD}^{+} \mathrm{CD}^{-}$thymocytes also had modestly reduced levels of IL-2 mRNA compared to circulating CD45R ${ }^{+} \mathrm{CD}^{+}$ $T$ cells. This may reflect the known heterogeneity within $\mathrm{CD}^{+}$ $\mathrm{CD}^{-}$thymocytes $(41,45,63)$ or additional immaturity in lymphokine production by this population.

The molecular mechanism for decreased IL-4 and IFN- $\gamma$ gene transcription and protein production by neonatal or adult CD45R ${ }^{+} \mathrm{T}$ cells compared to the adult $\mathrm{CD} 45 \mathrm{R}^{-} \mathrm{T}$ cell subset remains to be defined. The intracellular events involved in the induction of lymphokine gene transcription in $T$ cells have been best characterized for the IL- 2 gene, and suggest that two signals-an elevation in the intracellular concentration of calcium $\left[\mathrm{Ca}^{2+}\right]$ and activation of protein kinase $\mathrm{C}(\mathrm{PKC})$-are required (64), although a $P K C$-independent pathway may also exist (65). Neonatal and adult $T$ cells appeared to share similar requirements for the induction of all three of these lymphokine transcripts: in the presence of PMA, a direct PKC activator, the calcium ionophore ionomycin was consistently superior to Con A, which, in turn, was more efficient than anti-CD3 MAb for inducing IL-2, IFN- $\gamma$, and IL-4 mRNA in either adult or neonatal $T$ cells. These results suggest that the initial signal transduction pathways for IL-2, IL-4, and IFN- $\gamma$ gene expression are similar in neonatal and adult $T$ cells. Because IL-2 mRNA expression was comparable in neonatal and adult $T$ cells under the conditions of activation we employed, and because reduced IL-4 and IFN- $\gamma$ gene transcription was seen with stimuli that would bypass early steps in this signal pathway, the differences observed may be mediated by alternative signal transduction events or events occurring after elevation of $\left[\mathrm{Ca}^{2+}\right]$ and PKC activation. It is also possible that reduced transcription might result from alterations in the interaction of trans-acting factors with regulatory regions of the IL-4 and IFN- $\gamma$ genes. These possibilities are not mutually exclusive and are avenues for future investigation.

We can only speculate as to the potential advantage to the immune system of limiting most IFN- $\gamma$ production and virtually all IL-4 production to a memory T cell population. Possibly, this might focus the effects of these lymphokines onto suitably responsive effector cells, such as B cells or cytotoxic $T$ cells which have also been previously primed by antigen. It is interesting in this regard that exogenous IL-4 can inhibit B cell proliferation and the generation of $\mathrm{T}$ cell-mediated cytotoxicity when added to in vitro lymphocyte cultures at early times, while later addition of IL- 4 is actually stimulatory; in contrast, IL-2 addition does not have this time-dependent inhibitory effect $(28,66,67)$. Expression of high amounts of IL-4 or IFN- $\gamma$ by $T$ cells during the primary immune response or during intrathymic development could have other deleterious consequences. For example, IL- 4 and IFN- $\gamma$ by virtue of their ability to increase class II MHC expression on a variety of hematopoietic cell types $(1,2)$, could predispose to autoimmune reactivity at a critical stage of immunological development. Future in vivo experiments in which IL- 4 or IFN- $\gamma$ are overexpressed by $\mathrm{T}$ lineage cells during early ontogeny may provide insight as to the physiologic significance of restricting most production of these lymphokines to secondary $\mathrm{T}$ cell responses.

Whereas both IL- 4 and IFN- $\gamma$ production by peripheral T cells appear dependent on whether these cells have been previously activated in vivo, our results also indicate that the capacity for IL-4 production was remarkably restricted compared to IFN- $\gamma$ throughout T cell ontogeny. IL- 4 mRNA was 
undetectable or markedly less abundant than IFN- $\gamma$ or IL-2 mRNA in activated $\mathrm{CD}^{+} \mathrm{CD}^{-}$thymocytes, as well as circulating neonatal and adult $\mathrm{T}$ cells, and previous studies have demonstrated that this is also true for lymphoid tissue-associated $T$ cells from mice or humans $(4,68)$. Based on the results of in situ hybridization for lymphokine mRNA, this low level of production was due to the rarity of IL-4 producing cells. These findings suggest that during intrathymic as well as extrathymic $T$ cell maturation, the capacity for $T$ cells to produce IL-4 is relatively restricted, indicating that IL-4 may play a more specialized role in mediating $T$ cell effector functions than does IFN- $\gamma$ or IL-2. It remains to be determined if particular T cells are permanently committed to produce IL -4 and/or IFN- $\gamma$ and the extent to which production of these lymphokines by primary $T$ cells is mutually exclusive, a situation commonly observed among long-term murine $\mathrm{CD}^{+} \mathrm{T}$ cell clones, but not among short-term murine or most human $\mathrm{CD}^{+} \mathrm{T}$ cell clones (69-73). Recently, mutually exclusive production of IL4 and IL-2 has been demonstrated for primary murine CD4 ${ }^{+}$ splenic $T$ cells, fractionated on the basis of reactivity with $\mathrm{mAb}$ against two uncharacterized $T$ lineage determinants $(74,75)$. It will be of interest to determine which of these $\mathrm{CD} 4^{+}$splenocyte populations secrete IFN- $\gamma$, and whether analogous surface markers will also identify human primary $\mathrm{T}$ cells with specific patterns of lymphokine production.

\section{Acknowledgments}

We thank Janice Hall and Colleen McCluskey for performing flow cytometric analysis and Michael Weaver for his technical assistance in carrying out nuclear transcription and in situ hybridization assay and Barbara Lovseth for secretarial assistance.

This work was supported by grants AI/HD-26940, HD-06706, HD18184, and AI-16760 from the National Institutes of Health and by grant R-336-83 from the United Cerebral Palsy Foundation.

\section{References}

1. Paul, W. E., and J. Ohara. 1987. B-cell stimulatory factor-1/interleukin 4. Annu. Rev. Immunol. 5:429-475.

2. Trinchieri, G., and B. Perussia. 1985. Immune interferon: a pleiotropic lymphokine with multiple effects. Immunol. Today. 6:131-136.

3. Paul, W. E. 1989. Pleiotropy and redundancy: T cell-derived lymphokines in the immune response. Cell. 57:521-524.

4. Lewis, D. B., K. S. Prickett, A. Larsen, K. Grabstein, M. Weaver, and C. B. Wilson. 1988. Restricted production of interleukin-4 by activated human $T$ cells. Proc. Natl. Acad. Sci. USA. 85:9743-9747.

5. Tedder, T. F., L. T. Clement, and M. D. Cooper. 1985. Human lymphocyte differentiation antigens HB-10 and HB-11. I. Ontogeny of antigen expression. J. Immunol. 134:2983-2988.

6. Tedder, T. F., M. D. Cooper, and L. T. Clement. 1985. Human lymphocyte differentiation antigens HB-10 and HB-11. II. Differential production of B cell growth and differentiation factors by distinct helper $\mathrm{T}$ cell subpopulations. $J$. Immunol. 134:2989-2994.

7. Sanders, M. E., M. W. Makoba, S. O. Sharrow, D. Stephany, T. A. Springer, H. A. Young, and S. Shaw. 1988. Human memory T lymphocytes express increased levels of three cell adhesion molecules (LFA-3, CD2, and LFA-1) and three other moleucles (UCHL1, CDw29, and Pgp-1) and have enhanced IFN- $\gamma$ production. J. Immunol. 140:1401-1407.

8. Sanders, M. E., M. W. Makgoba, and S. Shaw. 1988. Human naive and memory T cells: Reinterpretation of helper-inducer and suppressor-inducer subsets. Immunol. Today. 9:195-199.

9. Akbar, A. N., L. Terry, A. Timms, P. C. L. Beverley, and G. Janossy. 1988 Loss of CD45R and gain of UCHL1 reactivity is a feature of primed T cells. $J$. Immunol. 140:2171-2178.

10. Bryson, Y. J., H. S. Winter, S. E. Gard, T. J. Fischer, and E. R. Stiehm. 1980. Deficiency of immune interferon production by leukocytes of normal newborns. Cell. Immunol. 55:191-200.
11. Wakasugi, N., and J.-L. Verelizier. 1985. Defective IFN- $\gamma$ production in the human neonate. I. Dysregulation rather than intrinsic abnormality. J. Immunol. 134:167-171.

12. Miyawaki, T., Seki, H., Taga, K., Sato, H., and Taniguchi, N. 1985. Dissociated production of interleukin- 2 and immune $(\gamma)$ interferon by phytohaemagglutinin stimulated lymphocytes in healthy infants. Clin. Exp. Immunol. 59:505-511.

13. Wilson, C. B., J. Westall, L. Johnston, D. B. Lewis, S. K. Dower, and A. R. Alpert. 1986. Decreased production of interferon gamma by human neonatal cells: Intrinsic and regulatory deficiencies. J. Clin. Invest. 77:860-867.

14. Lewis, D. B., A. Larsen, and C. B. Wilson. 1986. Reduced interferongamma mRNA levels in human neonates: evidence for an intrinsic $T$ cell deficiency independent of other genes involved in T cell activation. J. Exp. Med. 163:1018-1023.

15. Kamoun, M., P. J. Martin, J. A. Hansen, M. A. Brown, A. W. Diadak, and R. C. Nowinski. 1981. Identification of a human T lymphocyte surface protein associated with the E-rosette receptor. J. Exp. Med. 153:207-212.

16. Reinherz, E. L., P. C. Kung, G. Goldstein, and S. F. Schlossman. 1979. Separation of functional subsets of human $\mathrm{T}$ cells by a monoclonal antibody. Proc. Natl. Acad. Sci. USA. 76:4061-4065.

17. Hansen, J. A., P. J. Martin, P. G. Beatty, E. A. Clark, and J. A. Ledbetter. 1984. In Leucocyte Typing. A. Bernard, L. Boumsell, J. Pausset, C. Milstein, and S. F. Schlossman, editors. Springer-Verlag, Inc., New York. 195-212.

18. Reinherz, E. L., P. C. Kung, G. Goldstein, R. H. Lovey, and S. F. Schlossman. 1980. Discrete stages of human intrathymic differentiation: analysis of normal thymocytes and leukemic lymphoblasts of T-cell lineage. Proc. Natl. Acad. Sci. USA. 77:1588-1592.

19. Ledbetter, J. A., L. M. Rose, C. E. Spooner, P. G. Beatty, P. J. Martin, and E. A. Clark. 1985. Antibodies to common leukocyte antigen p220 influence human T cell proliferation by modifying IL2 receptor expression. J. Immunol. 135:1819-1824.

20. Rose, L. M., A. H. Ginsberg, T. L. Rothstein, J. A. Ledbetter, and E. A. Clark. 1985. Selective loss of a subset of $T$ helper cells in active multiple sclerosis. Proc. Natl. Acad. Sci. USA. 2:7389-7393.

21. McMichael, A. J., and F. Gotch. 1987. T cell antigens: New and previously defined clusters. In Leucocyte Typing III. A. J. McMichael, editor. Oxford University, Oxford, England. 57-58.

22. Smith, S. H., M. H. Brown, D. Rowe, R. E. Callard, and P. C. L. Beverley. 1986. Functional subsets of human helper-inducer cells defined by a new monoclonal antibody, UCHL1. Immunology. 58:63-70.

23. Wilson, C. B., and J. S. Remington. 1979. Effects of monocytes from human neonates on lymphocyte transformation. Clin. Exp. Immunol. 36:511520.

24. Maryanski, J. L., E. De Plaen, and J. Van Snick. 1985. A simple panning method for the selection of cell surface antigen transfectants. J. Immunol. Methods. 79:159-165.

25. Chang, T. W., S. McKinney, V. Liu, P. C. Kung, J. Vilcek, and J. Le. 1984. Use of monoclonal antibodies as sensitive and specific probes for biologically active human $\gamma$-interferon. Proc. Natl. Acad. Sci. USA. 81:5219-5222.

26. Burchett, S. K., W. M. Weaver, J. A. Westall, A. Larsen, S. Kronheim, and C. B. Wilson. 1988. Regulation of tumor necrosis factor/cachectin and IL-1 secretion in human mononuclear phagocytes. J. Immunol. 140:3473-3481.

27. Glisin, V., R. Crkvenjakov, and C. Byus. 1974. Ribonucleic acid isolated by cesium chloride centrifugation. Biochemistry 13:2633-2637.

28. Widmer, M. B., R. B. Acres, H. M. Sassenfeld, and K. H. Grabstein. 1987 Regulation of cytolytic cell populations from human peripheral blood by $B$ cell stimulatory factor 1 (interleukin 4). J. Exp. Med. 166:1447-1455.

29. Gray, P. W., D. W. Leung, D. Pennica, E. Yelverton, R. Najarian, C. C Simonsen, R. Derynck, P. J. Sherwood, D. M. Wallace, S. L. Berger, et al. 1982. Expression of human interferon cDNA in $E$. coli and monkey cells. Nature (Lond.). 295:503-508.

30. Taniguchi, T., H. Matsui, T. Fujita, C. Takaoka, N. Kashima, R. Yoshimoto, and J. Hamuro. 1983. Structure and expression of a cloned cDNA for human interleukin-2. Nature (Lond.). 302:305-310.

31. Feinberg, A. P., and B. Vogelstein. 1983. A technique for radiolabeling DNA restriction endonuclease fragments to high specific activity. Anal. Biochem. 132:6-13.

32. Pardoll, D., B. J. Fowlkes, R. Lechler, R. Germain, and R. Schwartz. 1987 Early events in T cell development analyzed by in situ hybridization. J. Exp. Med. 165:1624-1638.

33. Efrat, S., S. Pilo, and R. Kaempfer. 1982. Kinetics of induction and molecular size of mRNAs encoding human interleukin- 2 and $\gamma$-interferon. Nature (Lond.). 297:236-239.

34. Efrat, S., and R. Kaempfer. 1984. Control of biologically active interleukin 2 messenger RNA formation in induced human lymphocytes. Proc. Natl. Acad. Sci. USA. 81:2601-2605.

35. Vaquero, C., J. Sanceau, P. Sondermeyer, and R. Falcoff. 1984. Kinetics of messenger accumulation coding for IFN- $\gamma$ related lymphocytes to modification in the poly (A) RNA population of activated human. Nucleic Acids Res. 12:2629-2640. 
36. Kronke, M., W. J. Leonard, J. M. Depper, and W. C. Greene. 1985. Sequential expression of genes involved in human $\mathrm{T}$ lymphocyte growth and differentiation. J. Exp. Med. 161:1593-1598.

37. Taniguchi, T. 1988. Regulation of cytokine gene expression. Annu. Rev. Immunol. 6:439-464.

38. Morimoto, C., N. L. Letvin, A. W. Boyd, M. Hagan, H. M. Brown, M. M. Kornacki, and S. F. Schlossman. 1985. The isolation and characterization of the human helper inducer T cell subset. J. Immunol. 134:3762-3769.

39. Morimoto, C., N. L. Letvin, J. A. Distaso, W. R. Aldrich, and S. F. Schlossman. 1985. The isolation and characterization of the human suppressor inducer T cell subset. J. Immunol. 134:1508-1515.

40. Clement, L. T., N. Yamashita, and A. M. Martin. 1988. The functionally distinct subpopulations of human $\mathrm{CD}^{+}$helper/inducer $\mathrm{T}$ lymphocytes defined by anti-CD45R antibodies derive sequentially from a differentiation pathway that is regulated by activation-dependent post-thymic differentiation. $J$. Immunol. 141:1464-1470.

41. Serra, H. M., J. F. Krowka, J. A. Ledbetter, and L. M. Pilarski. 1988. Loss of CD45R (Lp 220) represents a post-thymic T cell differentiation event. J. Immunol. 140:1435-1441.

42. Rothstein, D., S. Sohen, S. F. Schlossman, and C. Morimoto. 1989. CD45R is a functional and not a simple maturational marker for CD4 and CD8 cells in man. In Seventh International Congress of Immunology, Berlin (West) Gustav Fischer Verlag, Stuttgart. 248. (Abstr.)

43. Hayward, A. R., J. Lee, and P. C. L. Beverley. 1989. Ontogeny of expression of UCHL1 antigen on TCR-1 ${ }^{+}(\mathrm{CD} 4 / 8)$ and TCR $\delta^{+}$T cells. Eur. J. Im munol. 19:771-773.

44. Notarangelo, L. D., P. Panina, L. Imberti, P. Malfa, A. G. Ugazio, and A. Albertini. 1988. Neonatal T4 $4^{+}$lymphocytes: analysis of the expression of $4 B 4$ and 2H4 antigens. Clin. Immunol. Immunopathol. 46:61-67.

45. Fowlkes, B. J., and D. M. Pardoll. 1989. Molecular and cellular events of T cell development. $A d v$. Immunol. 44:207-264.

46. English, B. K., S. K. Burchett, J. D. English, A. J. Ammann, D. W. Wara and C. B. Wilson. 1988. Production of lymphotoxin and tumor necrosis factor by human neonatal mononuclear cells. Pediatr. Res. 24:717-722.

47. Seki, H., K. Taga, A. Matsuda, N. Uwadana, H. Masaki, T. Miyawaki, and N. Taniguchi. 1986. Phenotypic and functional characteristics of active suppressor cells against IFN- $\gamma$ production in PHA-stimulated cord blood lymphocytes. $J$. Immunol. 137:3158-3161.

48. Haas, A., S. Plager-Marshall, B. J. Ank, A. M. Martin, L. T. Clement, and E. R. Stiehm. 1987. Pediatric Res. 21:408A. (Abstr.)

49. Budd, R. C., J.-C. Cerottini, and H. R. MacDonald. 1987. Phenotypic identification of memory cytolytic T lymphocytes in a subset of Lyt- $2^{+}$cells. $J$ Immunol. 138:1009-1013.

50. Budd, R. C. J.-C. Cerottini, C. Horvath, C. Bron, T. Pedrazzini, R. C Howe, and H. R. MacDonald. 1987. Distinction of virgin and memory T lymphocytes: stable acquisition of $\mathrm{PgP}-1$ glycoprotein concomitant with antigenic stimulation. J. Immunol. 138:3120-3129.

51. Budd, R. C., J.-C. Cerottini, and H. R. MacDonald. 1987. Selectively increased interferon- $\gamma$ by subsets of $\mathrm{Lyt}-2^{+}$and $\mathrm{L} 3 \mathrm{~T}^{+} \mathrm{T}$ cells identified by expression of Pgp-1. J. Immunol. 138:3583-3586.

52. Powrie, F., and D. Mason. 1989. The MRC OX $-22^{-} \mathrm{CD}^{+} \mathrm{T}$ cells that help $B$ cells in secondary immune responses derive from naive precursors with the MRC OX-22+ CD4 ${ }^{+}$phenotype. J. Exp. Med. 169:653-662.

53. Frenkel, L. and V. Bryson. 1987. Ontogeny of phytohemagglutinin-induced gamma interferon by leukocytes of health infants and children: Evidence for decreased production in infants younger than 2 months of age. J. Pediatr. 111:97-100.

54. Chilmonczyk, B. A., M. J. Levin, R. McDuffy, and A. R. Hayward. 1985 Characterization of the human newborn response to herpes virus antigen. $J$. Immunol. 134:4184-4188.

55. Osborn, J. J., J. Dancis, and J. F. Julia. 1952. Studies of the immunology of the newborn infant. I. Age and antibody production. Pediatrics. 9:736-744.
56. Gerli, R., P. Rambotti, C. Cernetti, A. Velardi, F. Spinozzi, A. Tabilio, M. Martelli, F. Grignani, and S. Davis. 1984. A mature thymocyte-like phenotypic pattern on human cord circulating T-lymphoid cells. J. Clin. Immunol. 4:461468.

57. Wilson, M., F. S. Rosen, S. F. Schlossman, and E. L. Reinherz. 1985. Ontogeny of human $\mathrm{T}$ and $\mathrm{B}$ lymphocytes during stressed and normal gestation: Phenotypic analysis of umbilical cord lymphocytes from term and preterm infants. Clin. Immunol. Immunopathol. 37:1-12.

58. Hercerd, T., J. Ritz, S. F. Schlossman, and E. L. Reinherz. 1981. Comparative expression of T9, T10, and Ia antigens on activated human $\mathrm{T}$ cell subsets. Hum. Immunol. 3:247-259.

59. Powers, G. D., A. K. Abbas, R. A. Miller. 1988. Frequencies of IL-2 and IL-4-secreting $T$ cells in naive and antigen-stimulated lymphocyte populations. $J$. Immunol. 140:3352-3357.

60. Pure, E., K. Inaba, and J. Metlay. 1988. Lymphokine production by murine $\mathrm{T}$ cells in the mixed leucocyte reaction. J. Exp. Med. 168:795-800.

61. Swain, S. L., D. T. McKenzie, A. D. Weinberg, and W. Hancock. 1988. Characterization of $\mathrm{T}$ helper 1 and 2 cell subsets in normal mice. J. Immunol. 141:3445-3455.

62. Perussia, B., L. Mangoni, H. D. Engers, and G. Trinchieri. 1980. Interferon production by human and murine lymphocytes in response to alloantigens. J. Immunol. 125:1589-1595.

63. Lanier, L. L., J. P. Allison, and J. H. Phillips. 1986. Correlation of cell surface antigen expression on human thymocytes by multi-color flow cytometric analysis: implications for differentiation. J. Immunol. 137:2501-2507.

64. Crabtree, G. R. 1989. Contingent genetic regulatory events in T lymphocyte activation. Science (Wash. DC). 243:355-361.

65. Sussman, J. J., M. Mercep, T. Saito, R. N. Germain, E. Bonvini, and J. D. Ashwell. 1988. Dissociation of phosphoinositide hydrolysis and $\mathrm{Ca}^{2+}$ fluxes from the biological responses of a T-cell hybridoma. Nature (Lond.). 334:625-628.

66. Karray, S., T. De France, H. Merle-Beral, J. Banchereau, P. Debre, and P. Galanaud. 1988. Interleukin 4 counteracts the interleukin 2-induced proliferation of monoclonal B cells. J. Exp. Med. 168:85-94.

67. Jelinek, D. F., and P. E. Lipsky. 1988. Inhibitory influence of IL-4 on human B cell responsiveness. J. Immunol. 141:164-173.

68. Sideras, P., K. Funa, I. Zalcberg-Quintana, K. G. Xanthopoulos, P. Kisielow, and R. Palacios. 1988. Analysis by in situ hybridization of cells expressing mRNA for interleukin 4 in the developing thymus and in peripheral lymphocytes from mice. Proc. Natl. Acad. Sci. USA. 85:218-221.

69. Mosmann, T. R., H. Cherwinski, M. W. Bond, M. A. Giedlin, and R. L. Coffman. 1986. Two types of murine helper T cell clone. I. Definition according to profiles of lymphokine activities and secreted proteins. J. Immunol. 136:24382357.

70. Cherwinski, H. M., J. D. Schumacher, K. D. Brown, and T. R. Mosmann. 1987. Two types of mouse helper T cell clone. III. Further differences in lymphokine synthesis between Th1 and Th2 clones revealed by RNA hybridization, functionally monospecific bioassays, and monoclonal antibodies. J. Exp. Med. 166:1229-1244.

71. Kelso, A., and N. M. Gough. 1988. Coexpression of granulocyte-macrophage colony-stimulating factor, $\gamma$ interferon, and interleukins 3 and 4 is random in murine alloreactive T-lymphocyte clones. Proc. Natl. Acad. Sci. USA. 85:9189-9193.

72. Umetsu, D. T. H. H. Jabara, R. H. DeKruyff, A. K. Abbas, J. S. Abrams, and R. S. Beha. 1988. Functional heterogeneity among human inducer T cell clones. J. Immunol. 140:4211-4216.

73. Paliard, X, R. D. W. Malefijt, H. Yssel, D. Blanchard, I Chretien, J. Abrams, J. D. Vries, and H. Spits. 1988. Simultaneous production of IL-2, IL-4 and IFN- $\gamma$ by activated human $\mathrm{CD}^{+}$and $\mathrm{CD}^{+} \mathrm{T}$ cell clones. J. Immunol 141:849-855.

74. Hayakawa, K., and R. R. Hardy. 1988. Murine CD4 ${ }^{+} \mathrm{T}$ cell subsets defined. J. Exp. Med. 168:1825-1838.

75. Hayakawa, K., and R. R. Hardy. 1989. Phenotypic and functional alteration of $\mathrm{CD}^{+} \mathrm{T}$ cells after antigen stimulation. J. Exp. Med. 169:2245-2250. 